\title{
Vloga socialnega dela pri prehodu mladih s posebnimi potrebami na trg dela
}

\begin{abstract}
$\overline{\text { Današnjimladostnikisezodločitvamio poklicniprihodnostisrečujejo vse boljzgodaj. Veliketežave }}$ doživljajo zlasti mladi z določenimi ovirami, zato pridobijo status otroka s posebnimi potrebami in pozneje status invalida. Zaposlitev ima pomembno družbeno in psihološko funkcijo, saj omogoča socialno in ekonomsko neodvisnost, številne spremembe na tem področju pa so pahnile iskalce zaposlitve $v$ boj z brezposelnostjo in fleksibilnimi oblikami zaposlitve. Pri kompleksnem reševanju problemabrezposelnostimladihs posebnimipotrebamipaselahkokotpodpornistebervključujejo socialne delavke, ki skupaj z mladostnikom na prehodu soustvarjajo pripravo na trg pridobitnega dela. Takšno socialno deloje ustvarjalno, potekav dialogu inje usmerjeno krešitvam teruporabnika spodbujassocialnodelovnimi pristopi kaktivnivlogi pri iskanju poklica in delovnega mesta. Obtem se oblikuje tudi mreža delodajalcev, ki se vključujejo v zaposlovanje oseb z ovirami in jim ponujajo priložnosti za pridobivanje delovnih izkušenj v realnem delovnem okolju. Takšni delodajalci so družbeno odgovorni, hkrati pa so upravičeni do subvencij in nagrad za zaposlovanje invalidov.
\end{abstract}

Ključne besede: aktivna politika zaposlovanja, zaposlitvena rehabilitacija, socialna vključenost, brezposelnost, invalidi.

Katja Verbovšek Zabukovec, magistrica socialnega dela, je zaposlena v Centru za poklicno rehabilitacijo na Univerzitetnem rehabilitacijskem inštitutu RS - Soča. Dela na projektu Prehod mladih s posebnimi potrebami na trg dela. Kontakt: katja.verbovsek@ir-rs.si.

\section{Role of social work during the transition of young people with special needs into the workforce}

Today's youth progressively face decisions that affect their future employment, confronting major obstacles, especiallyyouth with certain disabilities, which leads to receiving the status of a child with special needs and later the status of a disabled person. Employment has an important societal and psychological function as it enables social and economic independence. The number of changes in this field has pushed employment seekers to fight unemployment and flexible forms of employment. Regarding the search of a solution to a complex unemployment problem of youth with special needs, social workers can be included as a support pillar, co-creating the preparation process for the market for gainful employment together with the young person in transition. Such social work is creative, works through dialogue and is solution-oriented, using social work approaches to encourage the user to take an active role in finding a profession and a workplace where they could demonstrate their knowledge. During this interaction a network of employers is formed, which engages in the process of employing the people with disabilities, and offers them opportunities to gain work experience in a genuine work environment. Such employers are socially responsible and at the same time entitled to subsidies and rewards for the employment of people with disabilities.

Key words: active employment policy, occupational rehabilitation, social inclusion, unemployment, disabled.

Katja Verbovšek Zabukovec, MA in Social work, is employed at the Center for vocational rehabilitation at the University Rehabilitation Institute Republic of Slovenia - Soča, where she works on the project Transition of young people with special needs to the labour market. Contact: katja.verbovsek@ir-rs.si.

\section{Uvod}

Zahteve današnje družbe so na področju dela in iskanja zaposlitve velikanske in velikokrat so pričakovanja večja od tega, kar povprečen človek v resnici zmore dati. To je moč opaziti zlasti, če pogledamo področje zaposlovanja mladih ljudi s posebnimi potrebami, ki se, zaradi raznovrstnih zdravstvenih težav, pogosteje kot zdrave mlade osebe srečujejo s pomisleki delodajalcev pri zaposlitvi potencialnega kandidata. Podatki tudi kažejo, da mladi z ovirami po koncu 
izobraževanja pogosteje ostanejo doma in da se le redki zaposlijo. Ideja o enakovrednem vključevanju ljudi z ovirami $\mathrm{v}$ delo je tako pogosto neupoštevana zaradi zadržkov, ki izhajajo iz stigmatizacije, predsodkov in stereotipov. To potrjujejo tudi raziskave, ki kažejo, da so posebne potrebe posameznikov pogosto obravnavane kot oblika odklona in da negativna stališča do zaposlovanja ljudi z ovirami največkrat izvirajo iz nevednosti in strahu pred neznanim (Celarc, 2012). To nerazumevanje in odpor pred zaposlitvijo osebe z zdravstvenimi ovirami pa povzročata hitrejšo izločitev takšne osebe iz ožjega nabora kandidatov za določeno delovno mesto, saj zaradi diagnoze delodajalci pogosto le težko opazijo prednosti mladih s posebnimi potrebami na trgu dela (Uršič, 2003).

Mladi s posebnimi potrebami, ki v zaposlitvi vidijo priložnost za neodvisno življenje, se nemalokrat vrtijo $\mathrm{v}$ začaranem krogu iskanja pridobitnega dela in ugodnih okoliščin, v katerih bi lahko pokazali svoje znanje in spretnosti. Ta populacija je v prispevku predstavljena kot ena od ranljivih skupin, ki se pri razvoju karierne poti in na prehodu iz šolanja v svet dela srečuje s posebej velikimi izzivi.

$\mathrm{V}$ besedilu predstavljam problematiko zaposlovanja mladih ljudi, ki se srečujejo z raznovrstnimi zdravstvenimi težavami in si želijo vstopiti na trg dela, in jo povežem z izvajanjem pilotnega projekta »Prehod mladih s posebnimi potrebami na trg dela«, ki sta ga podprla Ministrstvo za delo, družino, socialne zadeve in enake možnosti ter Evropska unija iz Evropskega socialnega sklada. Cilj projekta, ki se bo sklenil konec avgusta 2022 in v katerega je bilo do konca junija 2019 vključenih 850 mladih s posebnimi potrebami iz vse Slovenije, je oblikovanje prostora za vnos sprememb z namenom čim večjega spodbujanja vključevanja mladih s posebnimi potrebami v svet pridobitnega dela; tako jim poskušamo zagotoviti priložnost, da na podlagi izpolnjevanja delovnih nalog pokažejo svoje znanje in spretnosti v realnem delovnem okolju in se s tem kar najbolj izognejo izgubi delovnega potenciala (Zovko Stele, Destovnik, Dolnišek in Arh, 2019).

V izvajanje projekta je vključenih več projektnih partnerjev iz različnih poklicnih skupin, a se v tem prispevku osredotočam na delo socialne delavke ${ }^{1}$, ki z usmerjenostjo na metode in koncepte, temelječe na dialogu, skupaj z mladimi s posebnimi potrebami soustvarja dragocen prispevek h krepitvi njihove moči. Socialna delavka ima v predstavljeni tematiki vlogo povezovalke, svetovalke in zagovornice mladih s posebnimi potrebami, ki se vključujejo v sfero dela, hkrati pa kot koordinatorka spodbuja mrežo delodajalcev k omogočanju zaposlitev temu ranljivejšemu delu populacije - mladim s posebnimi potrebami.

\section{Mladi s posebnimi potrebami}

Mladostništvo je obdobje, ki za posameznika pomeni prehod iz otroškega sveta v odraslega. Zgornja meja mladostništva pa se pod vplivom sodobnih demografskih in družbenih razmer zvišuje (Gradišnik, 2010). V skupino »mladih « se tako uvrščajo mladostniki in mlade odrasle osebe obeh spolov, stari od 15. do dopolnjenega 29. leta (Zakon o javnem interesu v mladinskem sektorju, 2010).

Izraz socialna delavka je v članku generičen izraz za oba spola. 
V času odraščanja začnejo mladostniki doživljati spremembe telesa, te vplivajo na razvoj samozavesti, hkrati pa jim družba začne določati omejitve in vedno večje obveznosti tako na področju izobraževanja kot tudi v sistemu formalnih in neformalnih dosežkov, na področju iskanja zaposlitve in uspehov v prostem času. 0 tem piše Ule (2000a, str. 18-19), ki trdi, da se zaradi vedno večjih pričakovanj od vseh čedalje več mladih srečuje s težavami, povezanimi $\mathrm{z}$ načrtovanjem svoje prihodnosti. Stiske se v tem ranljivem obdobju začnejo kopičiti in se pogosto pokažejo v obliki slabega učnega uspeha, nižje izobrazbe, težav s samopodobo, dodatnih zdravstvenih težav in pozneje omejenih možnosti zaposlitve. Osebnostno se mladi v tem času še oblikujejo, hkrati pa se že bojujejo za svoj položaj v družbi.

Možnosti za vstop v odraslost pa so se v zadnjih desetletjih precej zmanjšale, zato je mladina ranljivejša. Med mladimi se povečuje stopnja nezaupanja do družbe. Svet vse bolj doživljajo kot nepravičen, izkoriščevalen, vedno bolj tuj. Te občutke in dojemanje sveta lahko zaznamo na vseh področjih delovanja mladine, od vključevanja v vrstniško družbo in šolanja do prostega časa in pozneje iskanja dela (Ule, 2000b, str. 41-43).

Mladi s posebnimi potrebami pa se srečujejo še z ovirami, o katerih zdrave mlade osebe ne razmišljajo. Zato po besedah Mikuš Kos (1999) ni naključje, da za označevanje otrok in mladostnikov, ki ne morejo obvladovati običajnih zahtev, nalog, obremenitev, uporabljamo izraz »otroci s posebnimi potrebami«. Izraz »posebne potrebe«, ki ga uporabljajo na področju vzgoje in izobraževanja, opisuje otroke in mladostnike z učnimi, vedenjskimi in čustvenimi težavami. V Sloveniji je zelo uveljavljen in označuje skupine z ovirami, primanjkljaji in motnjami na področjih, kot so gibanje, zaznavanje, govor, spoznavanje, čustvovanje, vedenje in učenje. Lavrinc (2009) dodaja, da je bilo v Beli knjigi o vzgoji in izobraževanju iz leta 1995 določeno, da ta pojem vključuje tako otroke $\mathrm{z}$ učnimi težavami kot nadarjene otroke.

Kar zadeva terminologijo, naj dodam, da so v predpisih s področja zdravstva in v Zakonu o zdravstvenem varstvu in zdravstvenem zavarovanju (2006) otroci s posebnimi potrebami opisani kot »otroci z motnjami v telesnem in duševnem razvoju«, na področju socialne varnosti pa je v uporabi nekoliko drugačen pojem: Zakon o starševskem varstvu in družinskih prejemkih (2014) uporablja izraz »otroci, ki potrebujejo posebno nego in varstvo«.

Mladi s posebnimi potrebami so po Zakonu o usmerjanju otrok s posebnimi potrebami (2011) posamezniki, ki se srečujejo z vsaj enim primanjkljajem. Med njimi so:

- motnje v duševnem razvoju,

- slepota in slabovidnost oziroma okvara vidne funkcije,

- gluhota in naglušnost,

- govorno-jezikovne motnje,

- gibalna oviranost,

- dolgotrajna bolezen,

- avtistične motnje,

- čustvene in vedenjske motnje. 
Mikuš Kos (1999) meni, da je ne glede na to, da bi se v stroki radi izognili diagnosticiranju in označevanju otrok in mladostnikov, za skupine s hujšimi motnjami poimenovanje $v$ medicinskem jeziku pomembno, zlasti če potrebujejo pomoč strokovnih služb, ki zahtevajo uradne administrativne odločitve (npr. za prešolanje, subvencije, prilagoditve). Kajti še preden oseba s posebnimi potrebami dobi pravico do pomoči strokovnega delavca, ki jo plačuje država, mora imeti njegova težava ime, saj je le tako upravičen do pomoči države. $\mathrm{Ob}$ tem pa je seveda treba upoštevati, da je vsem, ne glede na oznako ali oviranost, skupna pravica do dostojanstva, varnosti in enakovredne obravnave v družbi, da morajo biti ljudje z ovirami polnopravni in spoštovani člane skupnosti in vključeni v delovno okolje (Zaviršek, Zorn in Videmšek, 2002).

Za to pa je pomembno razumeti, s čim vse se izključene skupine in posamezniki srečujejo v vsakdanjem življenju in kaj sama izključenost (zaradi določenih ovir ali motenj) zanje pomeni. Leskošek (2009) trdi, da takšni posamezniki nosijo dvojno breme, saj so subjekti ali, bolje rečeno, objekti regulacij, čeprav so kot marginalizirani manj vidni. Meni, da je verjetneje, da bomo govorili o njih kot pa z njimi. In prav ta dvojna nevarnost je velik vir tveganja za človekovo dostojanstvo najbolj zapostavljenih skupin, med katere se uvrščajo tudi mladi s posebnimi potrebami.

\section{Vključevanje mladih s posebnimi potrebami na trg dela}

Mladi s posebnimi potrebami so ena od prikrajšanih skupin na trgu dela. Zanjo je značilna dinamika prehajanja med različnimi statusi, med katerimi je tranzicija iz izobrazbenega sistema na trg dela ena pomembnejših.

Glede stanja na trgu dela se položaj mladih slabša. Precej mladih ljudi je namreč po končanem šolanju brez zaposlitve ali pa se vrtijo v začaranem krogu zaposlitev za določen čas (Domene in Arim, 2016). Brezposelnost mladih v Evropski uniji je od dva- do trikrat višja od splošne stopnje brezposelnosti, med državami pa so velike razlike (Ignjatović in Trbanc, 2009).

V Sloveniji se je v gospodarski krizi zelo povečal problem prehoda mladih iz izobraževanja na trg dela. V obdobju 2008-2014 se je stopnja brezposelnosti med mladimi zelo povišala, leta 2015 se je stanje nekoliko izboljšalo, leta 2016 pa je bila stopnja registrirane brezposelnosti med mladimi nižja kot leto prej, a je bila skupina mladih iskalcev zaposlitve kljub temu še vedno v slabem položaju (Zovko Stele, Destovnik, Dolnišek in Arh, 2019).

Mladi v Sloveniji so izjemno izpostavljeni variacijam na trgu dela. To lahko razberemo tudi iz statistike Zavoda Republike Slovenije za zaposlovanje (2021), ki kaže, da je registrirana brezposelnost vseh mladih (15-29 let) konec januarja 2021 znašala $20,6 \%$, odstotek v mesecih leta 2020 se ne razlikuje občutno. Znotraj te skupine mladih pa je treba razmejiti mlade brez posebnih ovir pri vključevanju v vsakdanje življenje in mlade s posebnimi potrebami. Konec januarja 2021 je bilo med mladimi $2,4 \%$ posameznikov z ovirami. V tej skupini so pritiski še bolj izraženi, saj mnogi zaradi svoje drugačnosti težko enakovredno tekmujejo z vrstniki, ki so brez zdravstvenih ovir. 
Preden se mladi s posebnimi potrebami podajo v svet pridobitnega dela, imajo nekaj možnosti, ki jim pomagajo pri odločanju glede karierne poti. $\mathrm{Na}$ voljo sta jim pomoč in svetovanje svetovalne službe v šoli, študentom s posebnimi potrebami sta na voljo pooblaščena oseba za delo s študenti $s$ posebnimi potrebami in tutorski sistem za študente s posebnimi potrebami, informacije glede poklicne prihodnosti lahko pridobijo tudi prek Društva študentov invalidov Slovenije ali znotraj kariernega centra na univerzah ali pa na kariernih središčih v uradih za delo in v prostorih nekdanjih centrov za informiranje in poklicno svetovanje, obstaja pa tudi možnost celostne obravnave na Centru za poklicno rehabilitacijo Univerzitetnega rehabilitacijskega inštituta - Soča (tu dobijo mladi s posebnimi potrebami vpogled v svoje psiho-fizične zmožnosti).

Po šolanju pa sta jim na voljo najpogosteje le dve možnosti: neposredna zaposlitev ali prijava v register brezposelnih oseb na Zavodu RS za zaposlovanje. Med tema možnostma pa obstaja še vmesni prostor, v katerem obstanejo zlasti mnogi mladi s posebnimi potrebami, ki so po šolanju brezposelni, hkrati pa niso prijavljeni na Zavodu RS za zaposlovanje in so s tem prikrajšani za nekatere pomembne pravice.

Kljub žgočim problemom na področju zaposlovanja mladih s posebnimi potrebami obstaja nekaj programov in ukrepov, oblikovanih z namenom zvišanja stopnje zaposljivosti mladih po šolanju, v katere se lahko vključijo. Slovenija se te problematike loteva z naborom splošnih ukrepov aktivne politike zaposlovanja: s programi izobraževanja, usposabljanja, subvencij in (samo)zaposlovanja. Leskošek (2009) meni, da instrumenti aktivne politike zaposlovanja ne zajamejo kompleksnosti brezposelnosti mladih v celoti, saj so poenostavljeni, niso ciljno usmerjeni in se ne osredotočajo na raznovrstnost skupine. Avtorica ukrepom aktivne politike zaposlovanja očita spregled spreminjanja obeh parametrov problema: mladosti in zaposlovanja. Spremembe so hitre in obsežne in za mlade brez delovnih izkušenj in spretnosti, ustrezne izobrazbe in s šibkim dostopom do virov tudi usodne, ker jih dolgoročno izključijo s trga dela.

Prehod mladih s posebnimi potrebi iz šole na trg dela torej ni celovito in zadovoljivo urejen - manjka vmesni povezovalni sistem. Zato tudi v Sloveniji poskušamo posnemati dobre prakse tranzicije mladih $\mathrm{v}$ različnih evropskih državah in s pomočjo pilotnega projekta »Razvoj in izvajanje prehoda mladih s posebnimi potrebami na trg dela«, ki ga sofinancirata Republika Slovenija in Evropska unija iz Evropskega socialnega sklada, izboljšati zaposlitveni položaj mladih in sistemsko urediti ta prehod. Pri tem pa zlasti zmanjšati ponavljajoče se epizode brezposelnosti mladih s posebnimi potrebami in izboljšati sodelovanje med različnimi institucijami s področja šolstva, sociale, zaposlovanja in zdravstva ter spodbujati socialno vključenost oseb iz ciljne skupine. Eden od ciljev projekta pa je tudi umestitev storitve »Prehod mladih med storitve zaposlitvene rehabilitacije «, saj bo to omogočilo sistemsko ureditev problema prehoda mladih s posebnimi potrebami iz šole na trg dela ter pripomoglo k vzpostavitvi enotne zaposlitvene mreže za prehod iz šole na trg dela (Prehod mladih, b.d.). 
Izvajalec zaposlitvene rehabilitacije naj bi kot projektni partner, ki pozna specifiko dela z osebami z oviro, zagotovil enega od možnih izhodov iz projekta: - zaposlitev (podporna na odprtem trgu dela, zaščitna v zaposlitvenih centrih in invalidskih podjetjih, podpora s subvencijami ipd.),

- nadaljevanje izobraževanja,

- prijava na Zavodu RS za zaposlovanje.

Pri tem moramo upoštevati nujnost osebne motivacije posameznika pri iskanju zaposlitve in to, da je iskanje pravega delovnega mesta za osebo s posebnimi potrebami specifično in zahteva dodatne aktivnosti.

To pomeni, da je med drugim treba ustvariti razmere $v$ delovnem okolju, ki ustrezajo zdravstvenemu stanju iskalca zaposlitve, omogočiti prilagoditve delovnega mesta in olajšati delovne naloge, podpreti samozaposlovanje in finančno motivirati osebe s posebnimi potrebami in omogočiti zaposlitve $s$ posebnimi pogoji. Gre za integracijo oseb s posebnimi potrebami, zato je treba pri zaposlovanju upoštevati vidike, kot so: poklicni interes, zdravstveno stanje, spretnosti in sposobnosti osebe.

Mladim s posebnimi potrebami je treba zagotoviti, da se za določeno delovno mesto usposobijo, se zaposlijo, zaposlitev tudi zadržijo, v njej napredujejo ali pa spremenijo svojo poklicno kariero (Zakon o zaposlitveni rehabilitaciji in zaposlovanju invalidov, 2007).

\section{Pomen dela/zaposlitve}

Zaposlitev ima ne le ekonomski pomen za človeka, ampak tudi pomembno družbeno in psihološko funkcijo, ki omogoča socialno in ekonomsko neodvisnost in je temelj socialne varnosti in socialne integracije (Rapuš Pavel, 2005).

So se pa na področju zaposlovanja $v$ zadnjih desetletjih dogajale in se še vedno dogajajo velike in intenzivne spremembe, saj se je sfera dela korenito spremenila in pretresla stabilne razmere, $\mathrm{v}$ katerih je prevladovala zaposlitev za nedoločen čas. Razmere postajajo vse bolj negotove, saj se povečujeta število fleksibilnih zaposlitev in brezposelnost (Leskošek, 2009).

Kriza zaposlitev in spremenjeni pogoji za vstop na trg dela pa oblikujejo in potencirajo ranljive skupine in povečujejo tveganje socialne izključenosti tistih, ki so že sicer v marginaliziranem družbenem položaju.

Mencin Čeplak (2000, str. 125) opozarja, da se strah pred nezaposlenostjo povečuje in se pomika po starostni lestvici navzdol. Zato po navedbi Trbanc (2005) veliko več mladih podaljšuje izobraževanje z namenom odlaganja zaposlitve. To lahko na iskalcih zaposlitve pusti posledice, kot so: občutki zmanjšanega statusa in ugleda $v$ družbi, negativen odnos do dela, slabša samopodoba in zmanjšano psihično zdravje, manjše kompetence, večja anksioznost in melanholija, socialna izključenost, manjše splošno zadovoljstvo z življenjem (Pohlan, 2019). Grzenda (2019) meni, da so posledice dolgotrajne brezposelnosti najobčutnejše pri mlajši in srednji generaciji, saj je vloga dela pri teh starostnih skupinah najpomembnejša.

Žal pa je tako doživljanje postala realnost marsikoga, saj se na splošno vse skupine mladih srečujejo z velikimi težavami pri pridobivanju prve zaposlitve. 
Leskošek (2009) meni, da je večina mladih zaposlenih za določen čas, se pravi, da zlahka preidejo v brezposelnost. Takšne oblike zaposlitve se redko razvijejo v trajnejše oblike, to pa za mlade pomeni novo tveganje, saj jim takšna oblika dela ne omogoča prave neodvisnosti.

Eden od pomembnejših prehodov mladih je prav prehod iz šolanja v zaposlitev. V resnici pa visoko izobraženi mladi vse pogosteje doživijo prehod iz izobraževanja v brezposelnost. Mladi se po navedbah Leskošek (2009) sicer zavedajo, da zaposlitev ni več nekaj, kar se pridobi z lahkoto, vendar ne pričakujejo, da bo brezposelnost trajala dalj časa. Zaradi preoblikovanja dela in oblik zaposlitev se zadeve vse bolj pomikajo v smer iskanja nestandardnih oblik zaposlitve in zaposlovanja v »sivi coni«, kot to poimenuje Rener (2000, str. 101).

\section{Zaposlovanje mladih s posebnimi potrebami: ovira ali priložnost za delodajalca?}

Delodajalci pogosto težko sprejmejo odločitev za zaposlitev mlade osebe, ki nima veliko delovnih izkušenj, če pa ima še pridružene specifične potrebe, motivacija za zaposlitev pri takšnem kandidatu skoraj izgine. Stereotipi, diskriminatorska praksa in predsodki še vedno niso preseženi in to kljub formalni prepovedi diskriminacije in uzakonjenim ukrepom, namenjenim izenačevanju možnosti oseb z ovirami in ozaveščanju javnosti o problematiki zaposlovanja oseb s posebnimi potrebami. Največji razlogi za to so: še vedno pomanjkljiva seznanjenost delodajalcev s problematiko zaposlovanja oseb z določenimi omejitvami, strah pred visokimi stroški prilagajanja delovnega mesta in skrb, da bo oseba z ovirami potrebovala preveč pomoči in bo pri delovnih nalogah manj učinkovita (Destovnik, 2019, str. 12-13).

Da bi to vendarle presegli, zakonska ureditev v Sloveniji (Zakon o zaposlitveni rehabilitaciji in zaposlovanju invalidov, 2007) predvideva obvezen delež oseb z ovirami v delovnem okolju, če skupno število zaposlenih presega dvajset oseb (t. i. kvotno zaposlovanje). Če delodajalec obveznosti ne izpolni, mora v Javni štipendijski, razvojni, invalidski in preživninski sklad Republike Slovenije (v nadaljevanju Sklad) plačati prispevek za spodbujanje zaposlovanja oseb z ovirami. Namesto tega prispevka pa se lahko delodajalec odloči za zaposlitev kandidata s statusom invalida. $V$ tem primeru lahko pridobi nekaj ugodnosti in finančnih spodbud, npr::

- Subvencija plače osebi z ovirami. To je pravica zaposlenega na zaščitenem delovnem mestu pa tudi v podporni zaposlitvi in invalidskem podjetju, ki jo uveljavlja oseba z ovirami pri Skladu zaradi doseganja nižjih delovnih rezultatov, ki so posledica njene oviranosti. Subvencija je odvisna od oblike zaposlitve.

- Plačilo stroškov prilagoditve delovnih mest in sredstev za delo ter plačilo stroškov podpornih storitev osebi z ovirami. Za to lahko delodajalec zaprosi Sklad z vlogo za plačilo primerne prilagoditve.

- Davčne olajšave za zaposlovanje ljudi z ovirami.

- Nagrada za preseganje kvote. Upravičenci so: delodajalci z najmanj dvajset zaposlenimi, ki presegajo kvoto; delodajalci z manj kot dvajset zaposlenimi, 
ki zaposlujejo ljudi z ovirami; samozaposleni posamezniki z ovirami, če njihova oviranost ni nastala kot posledica poškodbe pri delu ali poklicne bolezni pri tem delodajalcu.

- Oprostitev plačevanja prispevkov za obvezno pokojninsko in invalidsko zavarovanje za ljudi z ovirami, ki so zaposleni nad predpisano kvoto. 0 pravici odloča Sklad.

- Pravica do vključitve v program zaposlitvene rehabilitacije.

Tudi zaposleni s posebnimi potrebami lahko s svojimi specifičnimi znanji podjetju povečajo dodano vrednost, če le opravljajo naloge, ki se skladajo z njihovimi znanji in zmožnostmi in je delovno mesto primerno prilagojeno njihovim posebnostim. Potreben je samo družbeno odgovoren delodajalec, ki jim je pripravljen omogočiti preizkus znanja v realnem delovnem okolju.

\section{Uporaba konceptov socialnega dela pri delu z mladimi s posebnimi potrebami}

Ena od temeljnih doktrin socialnega dela je načrtovanje skupaj z uporabnikom in skupna izpeljava procesa reševanja problema. Pri tem je treba vzpostaviti oseben, neposreden stik in se že na samem začetku dogovoriti, kako bo potekalo soustvarjanje. Pri delu z mladimi pa je pri tem pomembno še to, da upoštevamo njihov specifični položaj dozorevanja in odraščanja, ko z njimi vzpostavljamo delovni odnos in spoznavamo njihov kompleksen življenjski svet, njihove strategije preživetja, kot jih poimenuje Poštrak (2015). Pri tem uporabljamo metodo socialnega dela s posameznim primerom in upoštevamo osnovno načelo zagotavljanja pozitivnih izkušenj in vključevanja v skupnost.

Schmidt (2001, str. 22) meni: »Nova paradigma na področju razumevanja oseb s posebnimi potrebami opušča staro segregativno pojmovanje in uvaja integrativno.« To je nediskriminatorsko pojmovanje, po katerem je človek individualno bitje ne glede na njegove poteze (Krapše, 2004). V dialogu se torej ne usmerjamo na pomanjkljivost osebe, temveč skupaj raziskujemo njen potencial in se trudimo za njeno čim boljšo integracijo v delovno okolje.

Pomembna vloga socialnega dela pri soustvarjanju skupne zgodbe z mladimi s posebnimi potrebami je predvsem krepitev moči mladih, ki so izgubili stik s svojimi viri moči, in pomoč na njihovi poti iskanja ustvarjalnosti in obvladanja življenja. Poseben izziv pri delu z odraščajočimi posamezniki je pogosto začetno vzpostavljanje stika z mladimi, ki so zaradi preteklih slabih izkušenj izgubili zaupanje $v$ strokovne delavce pa tudi $v$ prihodnost. Takrat uporabimo različne načine, s katerimi se mladostniku na prehodu v svet dela približamo. Pri tem je treba velikokrat pristopati ustvarjalno in na za mladostnike prijazen način, pri tem pa vedno definiramo sodelovanje kot delovni odnos, ki socialne delavce in uporabnike opiše kot sodelavce v skupnem projektu, ki imajo nalogo, da soustvarijo deleže v rešitvi (Čačinovič Vogrinčič, Kobal, Mešl in Možina, 2005).

Eno od pomembnejših načel dela v socialnem delu je perspektiva moči, ki poudarja odločitev, da strokovni delavci s svojim znanjem in spoštljivim ravnanjem omogočimo uporabnikom izkušnjo, da so kompetentni za svoje življenje, izkušnjo samospoštovanja in osebnega dostojanstva (Čačinovič Vogrinčič, 2005). 
Pri delu z mladimi s posebnimi potrebami je to načelo ključno, saj so bili v preteklosti v primerjavi z otroki, ki nimajo izkušnje bolezni ali druge oviranosti, prikrajšani za veliko pozitivnih izkušenj. To želimo nadoknaditi z aktiviranjem njihovih obstoječih virov in z ustvarjanjem novih.

V tem odnosu je zelo pogosto spregledano spoštovanje, čeprav je izjemno pomembno. Kot pomembno razsežnost svetovalnega odnosa ga opisuje Kristančič (1995), saj omogoča ustvarjalnejše in bolj zadovoljive vzajemne odnose. Če spoštujemo uporabnikovo osebnost, mu pomagamo, da sprejme samega sebe kot človeka, ki raste in se razvija ter pridobiva nove zmožnosti ter sposobnosti znajti se v realnosti vsakdanjega življenja. Pri delu z odraslimi osebami imamo spoštovanje za samoumevno, pri delu z mladimi pa na to pomembno vrednoto prevečkrat pozabimo, če mladim pripisujemo podrejen položaj.

Pri delu z mladimi je zelo uporaben tudi dogovorni pristop, saj na podlagi neposrednih doživetij in samoaktivnosti mlademu posamezniku s posebnimi potrebami približa svet dela in mu omogoči pridobitev pomembnih znanj in izkušenj, ki jih bo potreboval pri svoji nadaljnji karieri (Krajnčan in Habe, 2018). Le $\mathrm{z}$ lastnim udejstvovanjem bo spoznal sebe in svoje delovne navade $\mathrm{v}$ delovnem okolju, pridobil nova znanja in doživel uspeh na podlagi lastnega vložka.

Socialno delo se torej vseskozi opira na raziskovanje življenjskega sveta uporabnikov. Izhajamo iz obstoječega stanja: kakšni so mladostniki tu in zdaj. Tako naši nameni niso usmerjeni $v$ to, kako bomo mladostnike spremenili in oblikovali po vsakokratni predstavi o tem, kakšen naj bi bil idealni subjekt. Vprašanje je, kaj lahko skupaj z njimi storimo, da jim bo tu in zdaj bolje (Poštrak, 2015).

Socialno delo z mladostnikom s posebnimi potrebami je torej specifično delo, ker je treba pri vsakem posamezniku upoštevati ovire, s katerimi živi, vendar jih v delovnem odnosu ne smemo preveč poudarjati, ker lahko s tem mladostnika prikrajšamo za dobro izkušnjo. Prepričanje, da posameznik zaradi razvojne ali druge motnje določene aktivnosti ne bo zmogel, ga sili v omejevanje dejavnosti. Zato so potrebni aktivno sodelovanje, spodbujanje, skupno raziskovanje in soustvarjanje, saj mu zbudijo občutek, da ob podpori zna in zmore doseči cilj. Naloga socialne delavke pri tem je, da pomaga mladostnikom pri integraciji v okolje v skladu z njihovimi zmožnostmi. To jim da moč za razvijanje pozitivne samopodobe.

Preden se začnemo z uporabnikom ukvarjati z njegovim konkretnim izzivom, ki se navezuje na iskanje zaposlitve ali karierne orientacije, je najprej treba sooblikovati spoštljiv in kakovosten delovni odnos, ki nam omogoča prehod na drugo stopničko dela - socialno delo z mladimi s posebnimi potrebami na področju zaposlovanja.

\section{Socialno delo in zaposlovanje}

Številni poslanstva socialnega dela ne povezujejo s področjem zaposlovanja. Predmet in aktivnosti stroke si namreč številni zamišljajo precej ožje in skromnejše. Vendar pa dejavnost socialnega dela zavzema celotno življenjsko situacijo človeka v družbi (Miloševič Arnold in Poštrak, 2003). Torej vključuje 
tudi položaj zaposlenih v delovnem okolju in položaj tistih, ki se na vstop na trg dela šele pripravljajo.

Ta pomembna stroka, ki razpolaga s specializiranim in sistematiziranim znanjem o človeku in družbi ter temelji na raziskovanju življenjskega sveta uporabnika, ki je strokovnjak na podlagi osebne izkušnje, pripomore k spodbujanju in razvijanju sposobnosti posameznikov ter njihovemu lažjemu delu in zadovoljevanju potreb. Socialno delo s svojimi metodami odpravlja ovire, ki preprečujejo razvoj in vključevanje v okolje. Posameznikom, še zlasti izključenim, pomaga pri prilagajanju na družbene spremembe, je pa tudi uporabna znanost, ki pomaga ljudem doseči zadovoljivo raven psihosocialnega funkcioniranja, in z védenjem o človekovem vedênju in medčloveških odnosih obravnava tudi položaj posameznikov v delovnem okolju (Miloševič Arnold in Poštrak, 2003).

Socialne delavke, ki delujemo na področju zaposlitvene rehabilitacije in svetovanja, svetujemo mladim s posebnimi potrebami glede karierne poti in jim pozneje tudi pomagamo pri premagovanju ovir pri iskanju zaposlitve. Smo v nenehnem stiku z delodajalci in oblikujemo mrežo delodajalcev, s katerimi dolgoročno sodelujemo. S socialnodelovnim pristopom smo v oporo mladi osebi s posebnimi potrebami in tudi organizaciji/delodajalcu pri reševanju težav, če se pojavijo v delovnem okolju ali pri pripravi na vstop na trg dela. $\mathrm{S}$ tem pripomoremo k vsestranski uspešnosti vseh vpletenih akterjev $\mathrm{v}$ delovnem odnosu.

V delovnem okolju, v katerega se vključi mlad človek s posebnimi potrebami (npr. za namen delovnega preizkusa, prakse, usposabljanja, zaposlitve), se socialne delavke trudimo s koordiniranjem in svetovanjem pripomoči $\mathrm{k}$ ustvarjanju boljšega delovnega okolja. Pri svojem delu upoštevamo mladega posameznika z ovirami, ga obravnavamo celostno, se zavzemamo za pravičnost pri ravnanju z zaposlenimi in svetujemo delodajalcem pri organiziranju in prilagoditvah delovnega mesta, da bi bilo prijaznejše za osebe z ovirami.

Pri vstopu mlade osebe s posebnimi potrebami na trg dela se sodelovanje uporabnika in socialne delavke začne $\mathrm{z}$ dogovorom o delu in vključitvi v programe, ki temeljijo na iskanju ustrezne zaposlitve ali pa nadaljnjega izobraževanja. Ta dogovor mora biti jasen, izrečen in zapisan. Temeljiti mora na soustvarjanju. Socialne delavke mlado osebo s posebnimi potrebami poučimo o trgu dela, o možnostih za pridobitev različnih delovnih izkušenj, programu in storitvah zaposlitvene rehabilitacije, o poteku dela, pri vsem tem pa nedvoumno opišemo svojo vlogo, vlogo delodajalca in poudarimo vlogo uporabnika kot prihodnjega delavca, ki bo odgovoren za svoj delež. Vse to oblikujemo v individualiziran načrt pomoči, ki je pomemben dokument o posameznikovih potrebah, zmožnostih, funkcioniranju, dejavnikih okolja in primanjkljajih ter nadaljnjih korakih in ciljih za prihodnost. V načrtu so opredeljene tudi vse posameznikove posebnosti (npr. tempo dela, oblike in metode dela, pripomočki, ki jih potrebuje pri delu) in druge oblike pomoči, potrebne, da bo optimalno napredoval pri svojem delu.

V središču delovnega odnosa mora potekati dialog, v katerem skupaj z mladimi z ovirami raziskujemo stiske in možne rešitve. Skupaj ugotavljamo, kako 
do želenega izida. Socialna delavka daje pomembne informacije in predloge in je pri tem osebna zaradi osebnega odziva in empatičnega ravnanja. Z etiko udeleženosti pokaže, da odstopa od ukazovanja in si pomaga s sodelovanjem, v katerem nihče ne zlorablja svoje moči. Ključna pri tem delu pa je uporaba koncepta perspektive moči, saj pri vsakem kandidatu za zaposlitev iščemo njegove odlike (Čačinovič Vogrinčič, 2007).

Temeljne naloge socialnega dela na področju zaposlovanja so svetovanje, interveniranje, posvetovanje, informiranje, motiviranje, spremljanje in koordinacija. Izvajamo jih s posebnim odnosom, ki vključuje dogovarjanje, sodelovanje in povezovanje (Miloševič Arnold, 2000).

Pri delu z mladimi iskalci zaposlitve se velikokrat srečamo s prav posebnimi izzivi, zato moramo uporabljati različne metode dela in biti pri načrtovanju predvsem ustvarjalno usmerjeni in vseskozi spodbujati samoiniciativnost in aktivnost kandidata za zaposlitev. To lepo opiše Račnik (2010), ki trdi, da je takšno delo umetnost usmerjanja in postavljanja vprašanj. Socialna delavka, ki mladega s posebnimi potrebami vodi skozi proces zaposlovanja, mora spretno postavljati vprašanja, $s$ katerimi mu pomaga odkriti možnosti za odkrivanje svojih potencialov. V socialnem delu si pri iskanju zaposlitve za mlade s posebnimi potrebami pomagamo z elementov kovčinga, ki spodbuja uporabnike, da poiščejo najboljše možne rešitve in odgovore v sebi. Takšno vodenje obsega pozorno poslušanje, povzemanje, vero $\mathrm{v}$ uspeh, zanimanje za sogovornika in pomoč osebi, da sama analizira problem in zanj najde rešitev, pri tem pa smo ves čas odkriti in spoštljivi. Tak način dela ima za posledico večjo motivacijo in boljše rezultate.

Socialne delavke, ki sodelujemo z mladimi s posebnimi potrebami, ki so na prehodu na trg dela, se trudimo, da bi bilo za mlado osebo s posebnimi potrebami v delovnem okolju ustrezno poskrbljeno na vseh ravneh vključevanja, torej od priprave na zaposlitev do spremljanja na delovnem mestu. Preučujemo tudi različne prilagoditve, na primer delovnega okolja, uvajanja $\mathrm{v}$ delo ter gradiv in tehničnih pripomočkov, pomembnih za delo.

\section{Sklep}

Brezposelnost je pojav, ki lahko, če je dolgotrajna, vpliva na izgubo delovnega potenciala mladih. Ule (2000b) meni, da je prav brezposelnost eden glavnih razlogov za socialno ranljivost, ki zmanjšuje posameznikov status in ugled $v$ družbi.

$\mathrm{V}$ povezavi z brezposelnostjo in zaposlovanjem mladih s posebnimi potrebami lahko sklenem, da po koncu izobraževanja pogosto ostanejo brez potrebne podpore in pomoči, čeprav sta prav tedaj ključni, saj dlje časa trajajoča odsotnost $\mathrm{z}$ delovnega okolja lahko vpliva na večje stiske mladih iskalcev zaposlitve in na izgubo že pridobljenih kompetenc, vse to pa povečuje njihovo nezaposljivost (Tabaj, Dolinšek Pernovšek in Destovnik, 2016). Kot trdijo omenjeni avtorji, v Sloveniji ni storitev oziroma službe, ki bi delovala kot vmesnik med šolo in trgom dela. Sicer obstajajo programi, ki so namenjeni podpori mladim s posebnimi potrebami na trg dela, vendar so službe, 
ki izvajajo takšne storitve, razkropljene po različnih institucijah in med seboj nepovezane, informacije za otroke in mladostnike na prehodu ter za njihove starše pa so pogosto težje dostopne.

Ena od možnosti podpore je tudi vključevanje mladih s posebnimi potrebami v projekt »Prehod mladih s posebnimi potrebami na trg dela«, katerega namen je ureditev tranzicije mladih iz šolskega sistema v delovno sfero ter reševanje problematike iskanja in ohranjanja zaposlitve na njihovi poti v samostojnost. Pri tem se kot pomemben podporni steber lahko vključijo socialne delavke, zaposlene pri izvajalcih zaposlitvene rehabilitacije. Ti v projekt vstopajo zaradi ustreznih strokovnih znanj, poznavanja specifik dela z mladimi s posebnimi potrebami ter poznavanja delovne zakonodaje.

Ta hip (2021) je oblika pomoči, ki se navezuje na karierno usmerjanje in pomoč pri iskanju primerne in ustrezne zaposlitve mladih z ovirami celostno zagotovljena le v okviru omenjenega projekta. Cilj je umestitev projekta med storitve zaposlitvene rehabilitacije, saj bi to omogočilo sistemsko in celovito ureditev problema prehoda mladih s posebnimi potrebami iz šole na trg dela in večjo povezanost resorjev ter več mladih s posebnimi potrebami, ki se bodo ob izhodu iz projekta zaposlili, nadaljevali šolanje, se prijavili na Zavod RS za zaposlovanje in nato v ustrezne programe, ki jih ta zagotavlja. Drugih takšnih programov do zdaj še ni toliko razvitih, da bi ciljni populaciji omogočala celostno pomoč in spremljanje pri vključevanju v svet dela.

$\mathrm{V}$ projektu delujejo različne poklicne skupine, poudarjam pa dragocen prispevek socialnega dela. Socialne delavke s svojim znanjem in spoštljivim ravnanjem omogočijo uporabnikom izkušnjo, da so kompetentni za svoje življenje - načelo perspektive moči (Čačinovič Vogrinčič, Kobal, Mešl in Možina, 2005). Cilj izvajanja različnih storitev, kot so karierno svetovanje, informiranje, analiza delovnih mest, izdelava načrta prilagoditev delovnega mesta, ocenjevanje doseganja delovnih rezultatov, pa je, da mlada oseba s posebnimi potrebami pridobi kompetence za enakovredno vključitev v sfero dela.

V članku predstavljena problematika prej še ni bila obravnavana tako celovito. Je pa iz zapisanega razvidno, da je na voljo še veliko manevrskega prostora za dopolnitev sistema v smeri povezovanja deležnikov na trgu dela, izobraževalnega in zdravstvenega sistema, za soustvarjanje čim boljših zaposlitvenih izhodov za mlade s posebnimi potrebami. To pa je tudi cilj, ki ga vsak dan uresničujemo socialne delavke, zaposlene na področju zaposlovanja.

\section{Viri}

Celarc, A. (2012). Stališča do oseb z invalidnostjo v različnih organizacijskih okoljih (Magistrsko delo). Ljubljana: Fakulteta za družbene vede.

Čačinovič Vogrinčič, G. (2005). Socialno delo z družinami: študijsko gradivo za šolsko leto 2005-2006. Ljubljana: Fakulteta za socialno delo.

Čačinovič Vogrinčič, G. (2007). Socialno delo z družino. Ljubljana: Fakulteta za socialno delo.

Čačinovič Vogrinčič, G., Kobal, L., Mešl, N., \& Možina, M. (2005). Vzpostavljanje delovnega odnosa in osebnega stika. Ljubljana: Fakulteta za socialno delo. 
Destovnik, K. (ur.) (2019). Spodbujajmo zaposlovanje invalidov: priročnik. Ljubljana: Združenje izvajalcev zaposlitvene rehabilitacije v Republiki Sloveniji.

Domene, J. F., \& Arim, R. G. (2016). Associations between depression, employment, and relationship status during the transition into the workforce: a gendered phenomenon? Canadian Jorunal of Counselling and Psychoterapy, 50(1), 35-50.

Gradišnik, U. (2010). Uporaba umetnostnih izraznih sredstev v socialnem delu z otroki in mladostniki (Diplomsko delo). Ljubljana: Fakulteta za socialno delo.

Grzenda, W. (2019). Socioeconomic aspects of long-term unemployment in the context of the ageing population of Europe: the case of Poland. Economic Research - Ekonomska Istraživanja, 32(1), 1561-1582. Pridobljeno 13. 4. 2021 s https://doi.org/10.1080/133167 7X.2019.1638289

Ignjatović, M., \& Trbanc, M. (2009). Zaposlovanje in brezposelnost mladih: aktivni, fleksibilni in prilagodljivi. V T. Rakar, \& U. Boljka (ur.), Med otroštvom in odraslostjo: analiza položaja mladih v Sloveniji 2009 (str. 39-56). Ljubljana: Ministrstvo za šolstvo in šport, Urad Republike Slovenije za mladino: Inštitut Republike Slovenije za socialno varstvo.

Krajnčan, M., \& Habe, D. (2018). Doživljajska pedagogika v Sloveniji skozi teorijo in prakso. V M. Marovič, \& A. Sinjur (ur.), Večdimenzionalnost socialnopedagoških diskurzov (str. 189-205). Pridobljeno 13. 4. 2017 s https://www.researchgate.net/publication/326136665_Dozivljajska_pedagogika_v_Sloveniji_skozi_teorijo_in_prakso

Krapše, Š. (2004). Otroci s posebnimi potrebami. Nova Gorica: Educa.

Kristančič, A. (1995). Svetovanje in komunikacija. Ljubljana: AA Inserco.

Lavrinc, T. (2009). Vključevanje oseb s posebnimi potrebami v lokalno okolje (Magistrsko delo). Ljubljana: Pedagoška fakulteta.

Leskošek, V. (2009). Zaposlitvene možnosti mladih. Socialno delo, 48(4), 207-214.

Mencin Čeplak, M. (2000). Šola ter zgodbe o (pre)velikih pričakovanjih in izgubljenih iluzijah. V M. Ule, T. Rener, M. Čeplak Mencin, \& B. Tivadar (ur.), Socialna ranljivost mladih (str. 119-142). Ljubljana, Šentilj: Ministrstvo za šolstvo in šport, Urad RS za mladino, Založba Aristej.

Mikuš Kos, A. (1999). Različnim otrokom enake možnosti. Ljubljana: Zveza prijateljev mladine Slovenije.

Miloševič Arnold, V. (2000). Profesionalne vloge socialnih delavcev pri delu s starimi ljudmi. Socialno delo, 39(4/5), 253-262.

Miloševič Arnold, V., \& Poštrak, M. (2003). Uvod v socialno delo. Ljubljana: Študentska založba.

Pohlan, L. (2019). Unemployment and social exclusion. Journal of Economic Behavior and Organization, 164, 273-299. Pridobljeno 17. 3. $2021 \mathrm{~s} \mathrm{https://doi.org/10.1016/j.}$ jebo.2019.06.006

Poštrak, M. (2015). Koncepti socialnega dela z mladimi. Socialno delo, 54(5), 269-280.

Prehod mladih (b.d.). Pridobljeno 15. 3. 2021 s www.prehodmladih.si

Račnik, M. (2010). Postani najboljši vodja. Štore: Vodja si, treningi vodstvenih veščin M.R., s.p.

Rapuš Pavel, J. (2005). Delo je luksus: mladi o izkušnjah brezposelnosti. Ljubljana: Pedagoška fakulteta.

Rener, T. (2000). Ranljivost, mladi in zasebno okolje. V M. Ule, T. Rener, M. Čeplak Mencin, \& B. Tivadar (ur.), Socialna ranljivost mladih (str. 91-118). Ljubljana, Šentilj: Ministrstvo za šolstvo in šport - Urad RS za mladino, Založba Aristej.

Schmidt, M. (2001). Socialna integracija otrok s posebnimi potrebami v osnovno šolo. Maribor: Pedagoška fakulteta.

Tabaj, A., Dolinšek Pernovšek, T., \& Destovnik, K. (2016). Posnetek in analiza stanja problema prehoda mladih s posebnimi potrebami s šol na trg dela $v$ Sloveniji in predstavitev dobrih praks. Ljubljana: s. n. 
Trbanc, M. (2005). Zaposlovanje in brezposelnost mladih. V A. Črnak Meglič (ur.), Otroci in mladina v prehodni družbi: analiza položaja v Sloveniji (str. 161-188). Ljubljana, Maribor: Ministrstvo za šolstvo in šport - Urad RS za mladino, Založba Aristej.

Ule, M. (2000a). Spremembe mladosti ob koncu stoletja. V M. Ule, T. Rener, M. Čeplak Mencin, \& B. Tivadar (ur.), Socialna ranljivost mladih (str. 17-26). Ljubljana, Šentilj: Ministrstvo za šolstvo in šport - Urad RS za mladino, Založba Aristej.

Ule, M. (2000b). Družbeni izvori novih tveganj in negotovosti. V M. Ule, T. Rener, M. Čeplak Mencin, B. Tivadar (ur.), Socialna ranljivost mladih (str. 27-56). Ljubljana, Šentilj: Ministrstvo za šolstvo in šport - Urad RS za mladino, Založba Aristej.

Uršič, C. (2003). Zaposlovanje invalidov - med politiko in prakso. Zbornik predavanj, Ljubljana: Inštitut Republike Slovenije za rehabilitacijo, Zveza delovnih invalidov Slovenije.

Zakon o javnem interesu v mladinskem sektorju (2010). Ur. l. RS, št. 42/2010.

Zakon o starševskem varstvu in družinskih prejemkih (2014). Ur. l. RS, št. 26/2014.

Zakon o usmerjanju otrok s posebnimi potrebami (2011). Ur. l. RS, št. 58/2011.

Zakon o zaposlitveni rehabilitaciji in zaposlovanju invalidov (2007). Ur. l. RS, št. 16/2007.

Zakon o zdravstvenem varstvu in zdravstvenem zavarovanju (2006). Ur. l. RS, št. 72/2006.

Zaviršek, D., Zorn, J., \& Videmšek, P. (2002). Inovativne metode v socialnem delu: opolnomočenje ljudi, ki potrebujejo podporo za samostojno življenje. Ljubljana: Študentska založba.

Zavod Republike Slovenije za zaposlovanje. (2010). Registrirana brezposelnost. Pridobljeno 15. 5. 2021 s https://www.ess.gov.si/trg_dela/trg_dela_v_stevilkah/registrirana_brezposelnost

Zovko Stele, M., Destovnik, K., Dolinšek, T., \& Arh, M. (2019). Mladi s posebnimi potrebami na prehodu v zaposlitev. Šolsko svetovalno delo, 23(2/3), 57-67. 